\title{
Socio-economic and cultural strategy focused on the sustainable use of Chambira Palms (CUMARE) with indigenous communities in Guaviare - Colombia
}

\section{Ruby Acuña Ariza}

Universidad Nacional de Colombia sede Palmira, Facultad de Ingeniería y Administración

ryacunaa@unal.edu.com

\section{PROJËTICA}

\section{COMO CITAR ESTE ARTIGO:}

ARIZA, Ruby Acuña. Socio-economic and cultural strategy focused on the sustainable use of chambira palms (cumare) with indigenous communities in Guaviare - Colombia. Projética, Londrina, v. 11, n. 3, p. 70-89 , Nov. 2020. Edição especial FDaP. DOI: 10.5433/2236-2207.2020v11n3esp.p70. ISSN: 2236-2207.

DOI: 10.5433/2236-2207.2020v11n3esp.p70 
ABSTRACT: The purpose of this research was to establish a strategy oriented towards economic and social growth in two indigenous communities, comprised by (12) twelve women belonging to Tukano Oriental and Nukak Makú ethnic groups resettled in San José del Guaviare. This will generate a strengthening for local development of the region, focused on the sustainable use of Chambira palms located in the administrative department of Guaviare - Colombia, througly study applications and managing dynamics for the used vegetal species. By means of an experimental design supported by a mixed methodology, distributed in four phases: diagnosis, strategic formulation, implementation and evaluation. It was possible to evidence a clear absence of concertation mechanisms or productive alternatives agreed between the communities and the state, that give solution to the different problems present in the territory; likewise, an unnecessarily destructive use was identified in the harvest of the palm as a daily practice of the Nukak people in comparison with the process of non-destructive use adopted by the Tukano community. In conclusion, it is proposed the implementation of sustainable practices for adequated utilization, managing and transformation of vegetal fiber from native communities supported in an associativity strategy between base organizations and women from the involved etnies, generating exchange networks.

Palavras-chave: Indigenous. Cumare. Sustainable utilization. Guaviare. Associativity.

\section{INTRODUCTION}

The vegetable resource of the palm is intensely used by different human groups that inhabit the Amazon region, this represents a determining role for its sustenance, its housing and elaboration of multiple artifacts managing to satisfy the most basic necessities like food, construction materials, tools, medicines, among others. In 
addition to being present in the practical and symbolic activities of indigenous communities (MESA, 2011). Such artifacts built by communities reflect their thought express the collective recognition of the territory constituting a part of traditional manifestations of their culture in which their experiences are materialized by integration of codes, signs and symbols as a part of their conception of existence.

In this sense, we will focus in Astrocaryum Chambira Burret (AC) palm known commonly as Cumare, it rows over west in amazonic region from Venezuela to Peru and to west of Brazil, in Colombia it is distributed in low humid and steady lands with greater abundance, growing in Sandy -clay soils with good drainage and gallery forest of $100-500 \mathrm{~m}$ in elevation. It is often cultivated and conserved in slash and burn plots - chagras (GALEANO et al., 2010) between Chambira qualities we can identify that it is one of most exploited palm species providing high quality fibers in Colombia, which makes it object of attention in its Harvest and managing process from rural population environmental authorities and researchers (BERNAL; GALEANO, 2013) in this regard García et al. (2015) stands that use of Chambira's fiber is been registrated in 21 aborigine groups of Colombian Amazonia, where at least 14 products are fabricated: thread, wraps, fishing nets strainers hamacs, traps, arrows and harpoons, bags, mats, baskets, dress, belts, bracelets". Most of these products represent from $40 \%$ it $100 \%$ of artisan families income (GARCÍA CASTRO, 2013). Nevertheless, some communities bash palm in order to obtain Cumare's fruits or fiber choosing a destructive harvest (BRAÑAS; MASS HORNA, 2011), which leads to shortage in regions like eastern plains and Casanare (GARCÍA CASTRO, 2013). Thus, it is important to emphasize in endogenic resources conservation through diffusion of cultural and natural patrimony of the region. 
Fig. 1 - Integral use of the palm

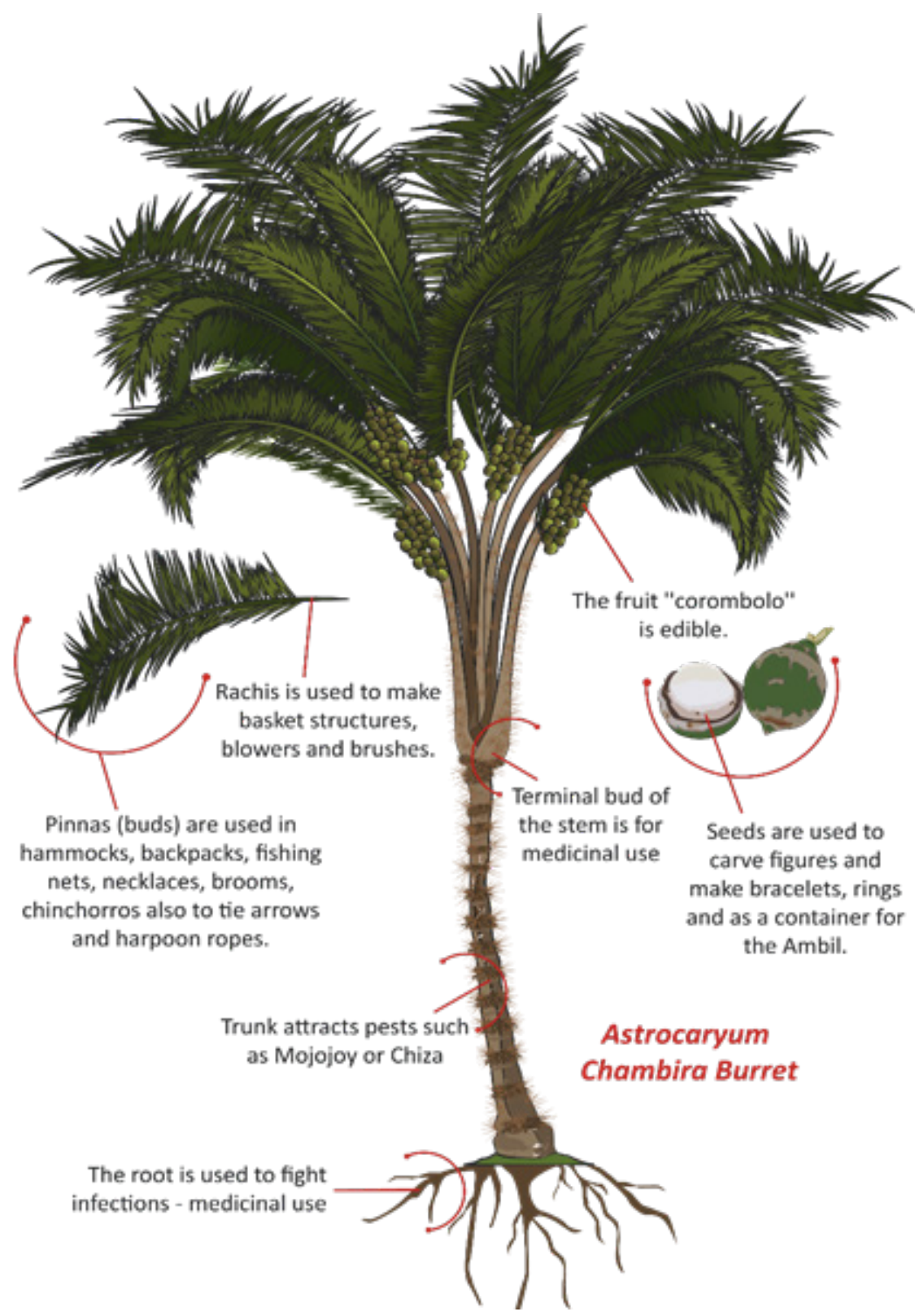

Font: Author. 
The Colombian northwest Amazon is currently home to different native peoples living in conditions of vulnerability configured by few employment possibilities that guarantee a stable income within the prevailing economic model and allow them to meet in a timely and adequate basic needs. These indigenous communities in modern times are part of a diversity of similar individuals among themselves; where the multicultural coexistence of that diversity is not expressed through the recognition to be different but, simply, its existence is often recognized isolated and distant (TOBAR; ZARATE; GROSSO, 2018). These disparities are reflected in the lack of job opportunities, low levels of education, discrimination and loss of the possibility of preserving a food sovereignty supported in the cultivation of their lands, generating a critical situation for these peoples. In this context, indigenous women are the most affected since they experience even more accentuated discrimination due to their situation of forced displacement and their condition coming from rural territories distant from population centers such as Vaupés, Mitú, Meta and Guaviare. Therefore, it is relevant to investigate the capacity of the community organization as a social actor to provide sustainability and feasibility to social projects that contribute to the development of communities through strategic planning, establishing useful connections to consolidate the way in which the community is projected, potentiates its strengths, protects and resignifies its knowledge (CARRERA MORALES, 2015).

In this measure, the research focuses on determining a socio-economic and cultural strategy that fosters economic growth and local development in the region, oriented towards the sustainable use of the Chambira palms located in the municipality of San José del Guaviare, department of Guaviare - Colombia, referring to the process of harvesting, post-harvest and transformation of the fiber, avoiding affecting the balance of the species by minimizing the environmental impact on the environment; starting from the diagnosis and analysis of the physical and mechanical characteristics of cumare vegetable fiber, with the interest of identifying and evaluating its behavior to be subjected to different transformation processes. 


\section{METHODOLOGY}

The study performed a characterization of physical and mechanical properties of the vegetable fiber (Astrocaryum Chambira Burret), collected from chagras and secondary forests located in the region of San José del Guaviare Colombia. An experimental design with tensile strength tests based on the ASTM D882-18 protocol was used for 20 tissue samples composed of thin fibers and tensile strength using the ASTM D3822-07 analyzing 22 filament specimens extracted from threads and discontinuous fibers. A statistical analysis ANOVA was made to the data thrown in the two tests comparing them with the behavior of the vegetable fiber Furcraea bedinghausii (FB), in addition, a qualitative study was made by means of a social cartography, where similarities, differences and relations between the collective perceptions of the participants were known, understanding their knowledge of the territory, the changes in the historical context in the management of the natural resources, contrasting the use and past handling with the present one. Finally, a sociocultural diagnosis was carried out to identify socioeconomic needs, causal factors, conditioning factors, resources and means of action to propose strategies.

\section{RESULTS AND DISCUSSION}

\subsection{Physical and Mechanical Analysis of Vegetable Fiber}

According to the physical and mechanical analysis, the average elastic limit of $8.82 \%$ compared to the FB that for its content of lignin reaches up $11.46 \%$ presenting the last one a highest elastic capacity (MANIMARAN et al., 2018). In table 1 and 2 is shown the relation between maximum effort (break) and a minimum effort (fluence), in accordance with the direction in which the A-sense fibers are woven, they withstand greater constant effort relative to the B-direction, in this 
Projética, Londrina, v. 11, n. 3 Esp IFDaP, p. 70-89, novembro 2020

way there was a significant decline on vegetable fiber resistance when it get to higher temperatures than $32^{\circ} \mathrm{C}$ and a relative humidity less than $50 \%$. While AC has a density of $0.3 \mathrm{~kg} / \mathrm{m} 3$ showing low tensile strength, FB has a density greater than $778 \mathrm{~kg} / \mathrm{m} 3$ favoring its ability to create light compounds (MANIMARAN et al., 2018). Also in the diameter measurement of vegetable fiber is difficult thanks to the variation of this in nature. However, it is assumed to be circular: FB has a diameter of $12.8 \mu \mathrm{m}(0.0128 \mathrm{~mm})$ and $\mathrm{AC}$ a diameter of $180 \mu \mathrm{m}(0.18 \mathrm{~mm})$ so AC provides more stability to the filament by increasing its ability to withstand stresses when woven.

Table 1 - Results of the stress test for samples A-sense.

\begin{tabular}{llll}
\hline \multicolumn{3}{c}{ A-SENSE } \\
\hline Property & Unds & Average & Standard deviation \\
\hline Tensile strength at break & $\mathrm{N}$ & 1134.941 & 339.903 \\
\hline Tensile strength at creep & $\mathrm{N}$ & 161.643 & 4.232 \\
\hline Maximum displacement & $\mathrm{mm}$ & 60.929 & 1062 \\
\hline \multirow{2}{*}{ Maximum deformation } & Fraction & 0.0419 & 0.0007 .94 \\
\cline { 2 - 4 } & $\%$ & 4.191 & 0.794 \\
\hline Modulus of elasticity & $\mathrm{Pa} / \mathrm{mm} 2$ & 0.465 & 0.17 \\
\hline
\end{tabular}

Font: Author.

Fig. 2 - Graphs stress vs. deformation A-sense.

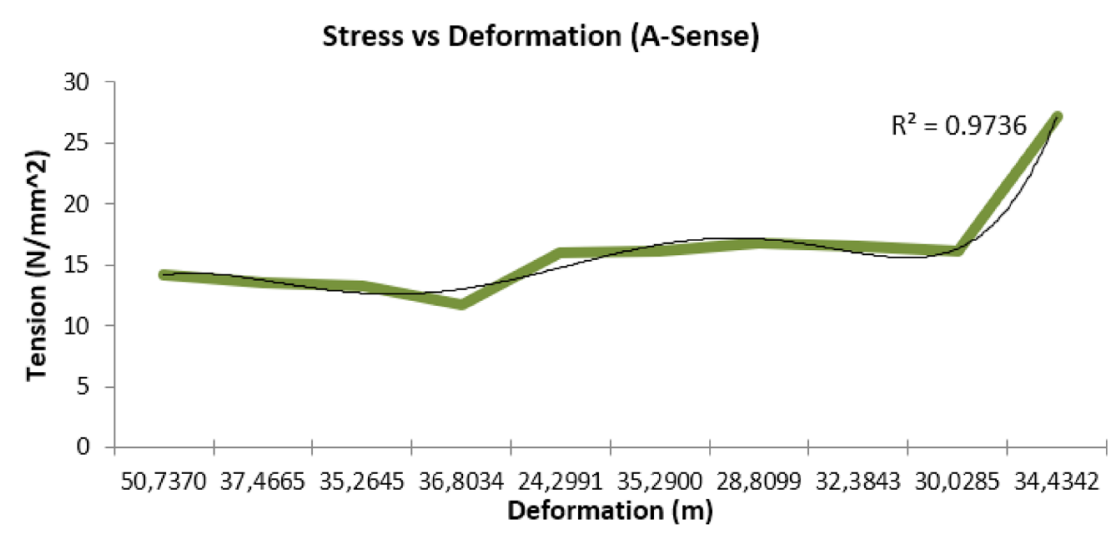

Font: Author. 
Fig. 3 - Graphs effort vs. deformation A-sense

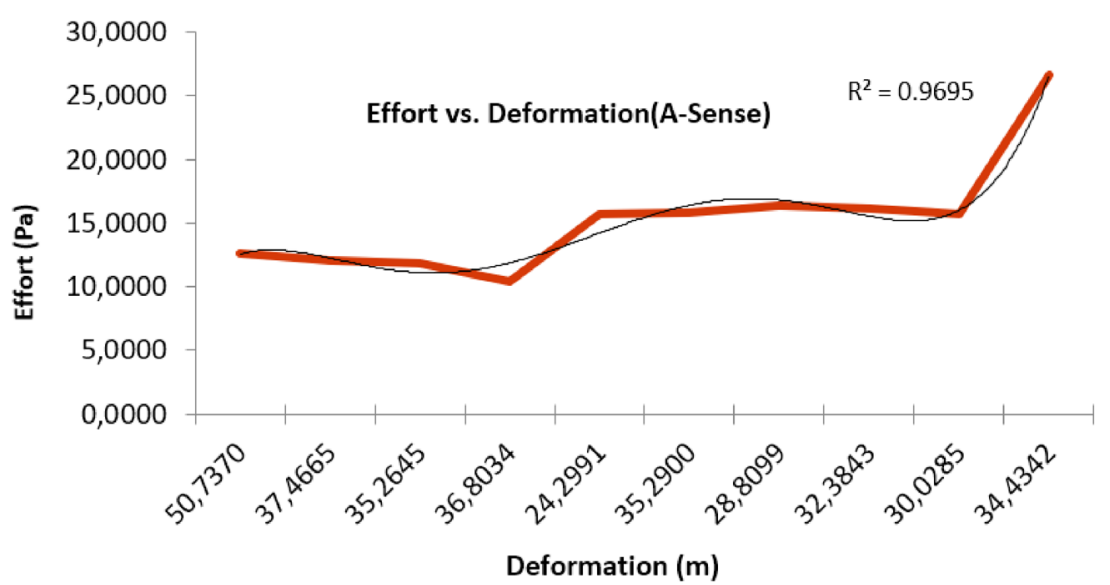

Font: Author.

Table 2 - Stress test results for B-sense samples

\begin{tabular}{llll}
\hline \multicolumn{4}{c}{ B-SENSE } \\
\hline Property & Unds & Average & Standard deviation \\
\hline Tensile strength at break & $\mathrm{N}$ & 791.159 & 219.537 \\
\hline Tensile strength at creep & $\mathrm{N}$ & 11.448 & 3.709 \\
\hline Maximum displacement & $\mathrm{mm}$ & 13.092 & 5.496 \\
\hline \multirow{2}{*}{ Maximum deformation } & Fraction & 0.0881 & 0.0243 \\
\cline { 2 - 4 } & $\%$ & 8.818 & 2.43 \\
\hline Modulus of elasticity & $\mathrm{Pa} / \mathrm{mm} 2$ & 0.696 & 0.339 \\
\hline
\end{tabular}

Font: Author. 
Fig. 4 - Graphs stress vs. deformation B-sense.

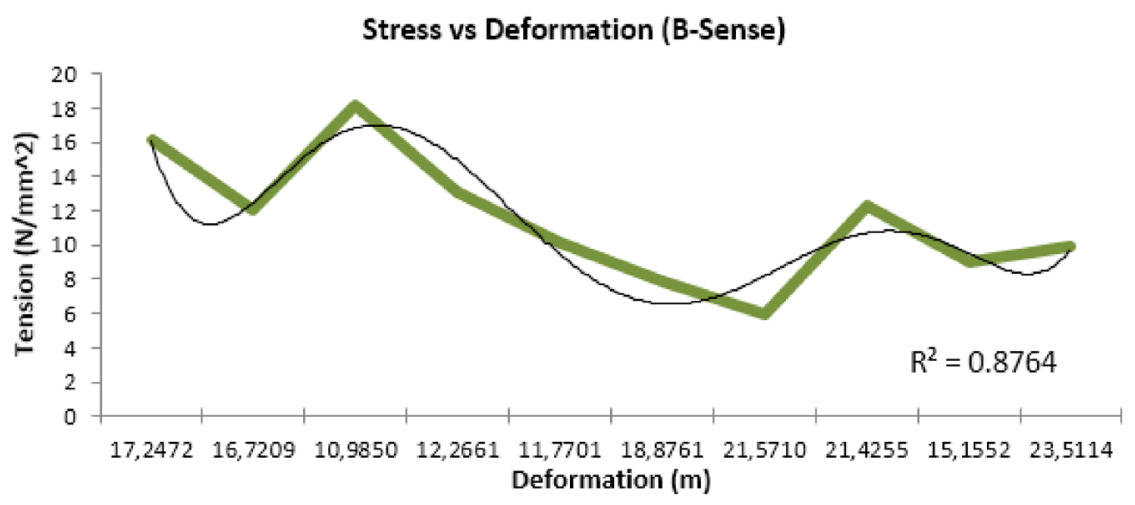

Font: Author.

Fig. 5 - Graphs effort vs. deformation B-sense.

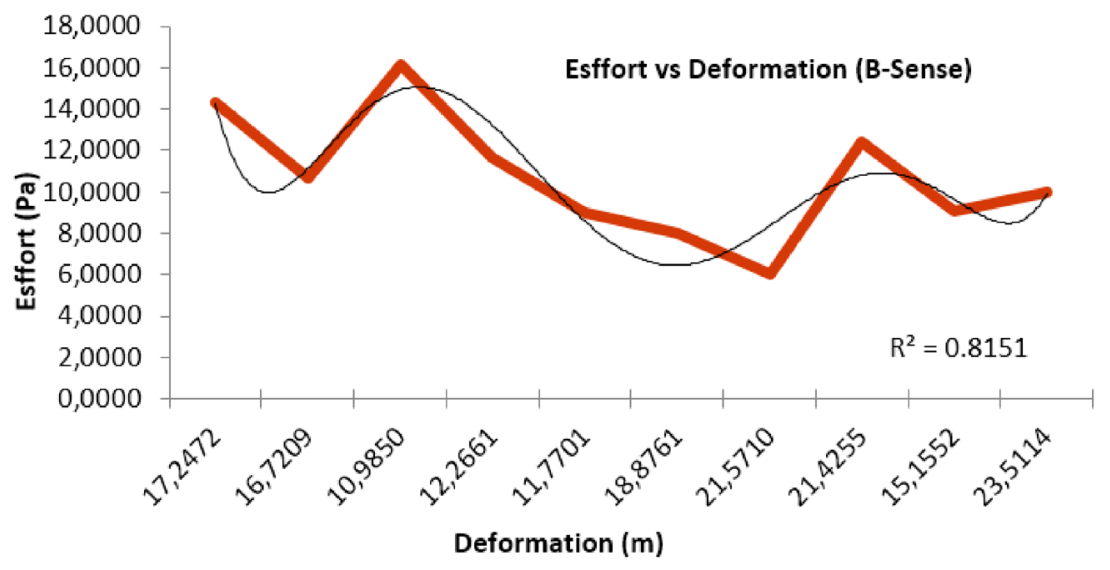

Font: Author. 


\subsection{Social Cartography of Guaviare}

Determinants such as deforestation, illegal logging, extensive cattle ranching, and overfishing of pipes and rivers were discussed. In addition to this, there is the active presence of insurgent groups (paramilitaries and guerrillas) that control the territory along with the disposition of land by the state to third parties. All this has limited the use and management of the territory in the indigenous communities losing access to areas of traditional use where they cultivated, harvested their food, they extracted cumare fiber and used fruits as raw material to make their handicrafts. At the same time, the collective memory was structured through a geographical map of the department as a symbolic and cultural product, locating zones of distribution of the species (secondary, primary and chagras forests), boundaries, and location of different ethnic communities (fig.7).

In this regard, the Tukano women located in the Arazá urban settlement, continuously referenced the areas of extraction of the cumare fiber with the establishment of army battalions, military bases and checkpoints of the police and the national army displaying an active presence of groups outside the law and of the Colombian armed forces in the region. The Nukak women of the Mayari community located in the Agua Bonita settlement have been practicing nomadism for decades, suffering from colonization processes and armed conflict. They comment that they no longer hunt or collect their food frequently, as the forests became pastures because of the intervention of the settlers, now having little access to areas where the cumare grows due to the inadequate distribution of the land that the state made by giving it to peasants settled in the sector. Likewise, the unnecessarily destructive harvesting practices adopted by this community do not benefit the chambira palm populations, causing the scarcity of the plant resource in the area (fig.6). 
Projética, Londrina, v. 11, n. 3 Esp IFDaP, p. 70-89, novembro 2020

Fig. 6 - Geographical location of departments with Astrocaryum Chambira crops in Colombia

Department investigated (Guaviare)

Departments where the species is absent

Departments where the species is located

Font: Author. 
Fig. 7 - Cartographic Map of Guaviare

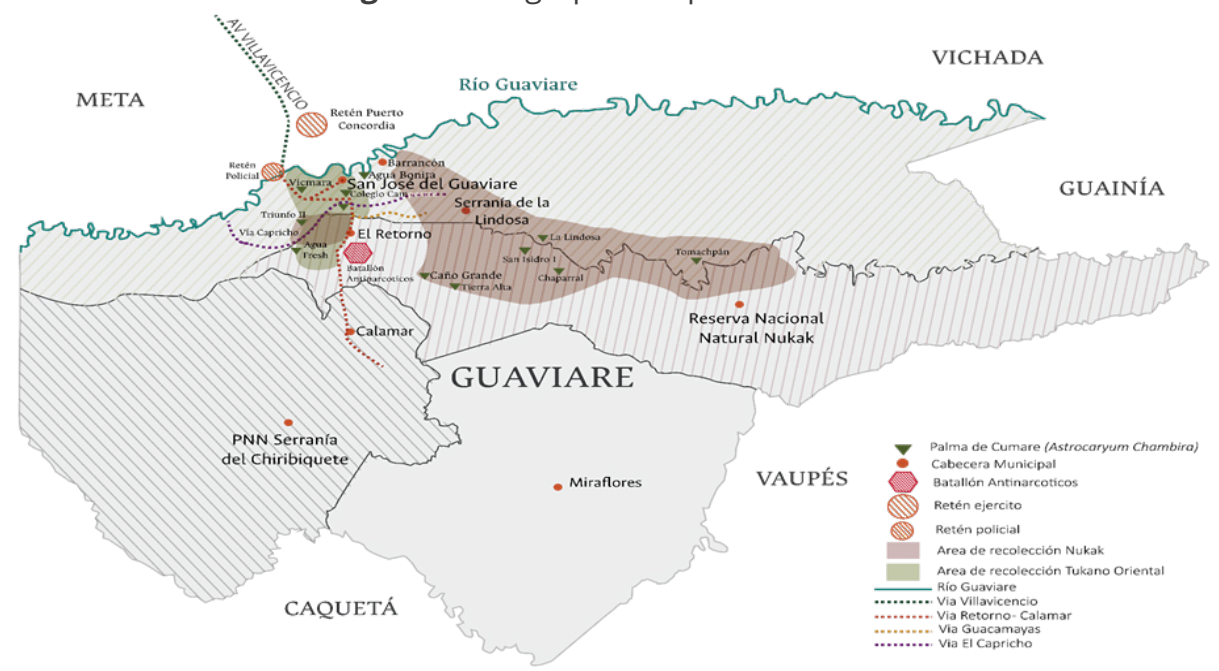

Font: Author.

\subsection{Harvesting, Post-Harvest and Processing of Cumare}

The traditional management of chambira palm populations in the region in terms of harvesting, processing of raw material, processing and marketing of items has been demarcated by ancestral practices still adopted by indigenous women of the two communities. The Tukanos moves for long journeys of road between 4 and 5 hours' round trip until the areas of collection of cumare, prefer to collect in adjacent lands to chagras, also near military checkpoints (police, army) by the proximity of cultivation areas. As far as the Nukak are concerned, they do not harvest but, they gather according to their needs, they make strategic trips to secondary forests near paths where settlers live, rarely go alone to collect cumare and take advantage of mobility to collect more fruits such as honey, fish and to lower seeds or fruits of other palms, these are the factors that help to mark the strategic areas of mobility. The women begin the trek making long journeys of 5 to 6 hours on the way and return another 5 hours, they look in morichales and stubble forest because in these conditions the cumare grows. 
In contrast, the two ethnic groups have different harvesting methods, the Nukak harvest without being guided by the fact that the palm has characteristics suitable for harvesting, practice an unnecessarily destructive use by tearing down the palm to cut the buds, lower its fruits and attract the Mojojoy (larva coleopteran) causing an intentional sacrifice of the cumare unlike the Tukano that use a nondestructive harvesting method by cutting the leaves and taking the fruits without knocking down the palm, using as a tool the crescent in which at one end they hook the bud and pull it hard to cut it, these practices were considered as one of the key axes in the decision making in the establishment of the action strategies. Having said this, the processing of the cumare is divided into the prior preparation of the fiber under appropriate drying conditions, cooking to prevent the fiber from deteriorating faster and staining, which includes the twisting of the fiber or spinning to obtain long and thick ropes joined by several filaments of yarn, this process provides stability and resistance to the fabric. Thus Chambira fiber is dyed with natural pigments and commercial dyes based on chemical anilines (artificial dyes) the Tukano occasionally use commercial products (instant powdered soda), on the other hand, the Nukak leave some fibers without staining because, they prefer the natural color of the fiber. Among the natural pigments used are:

- Pucapanga - Carayuru (Arrabidaea Chica) dark reddish color

- Achiote (Bixa Orellana) light reddish color

- Turmeric - Choique (Curcuma Longa) yellow color

- Beet (Beta Vulgaris) purple color

- Acai (Euterpe Precatoria) light purple color

The Tukanos add salt and lemon as binders to lighten the shades and better fix the color in the fiber, the Nukak do not use any biting to dye the fiber. 


\subsection{Social Design Applied to the Territory}

The immersion of the human being in situations corresponding to design proposes moving the focus of attention on objects and directing it towards people, their experiences and their contexts, necessarily involves displacing the current proposal of meaningless development by taking it to conscious design (ESCOBAR, 2016). Speaking from a strategic level of policy and economic promotion, design reflects a factor of addiction, creation and generation of value to the management of the territory, so one of the main weaknesses present in the design is the implementation of mechanisms focused on the mobilization of key skills of the human being within a creative development process, expressed to add value to the local product (MOLLENHAUER; HORMAZÁBAL, 2014). Starting from the design approach aimed at social justice, innovative methodologies have been developed in the intervention and interaction with communities, making their implementation connect with an environmental justice of the territory and the landscape by creating the possibility of maintaining and renewing through the resistance of a community while reorienting its future (ESCOBAR, 2016). And it transforms it towards collective benefit.

\subsection{Formulation of Action Strategies}

Three main areas of interest were classified (fig. 8), oriented in a transversal way by active participation and group decision-making among women. proposing in this way to work collectively through meetings (workshops) of co-creation with the two communities, orienting them assertively in order to give added value and monetary to the handicraft product strengthening the relationship between craftsmen, tourists and merchants (GARCíA et al., 2015). 
Projética, Londrina, v. 11, n. 3 Esp IFDaP, p. 70-89, novembro 2020

Fig. 8 - Establishment of strategies for action

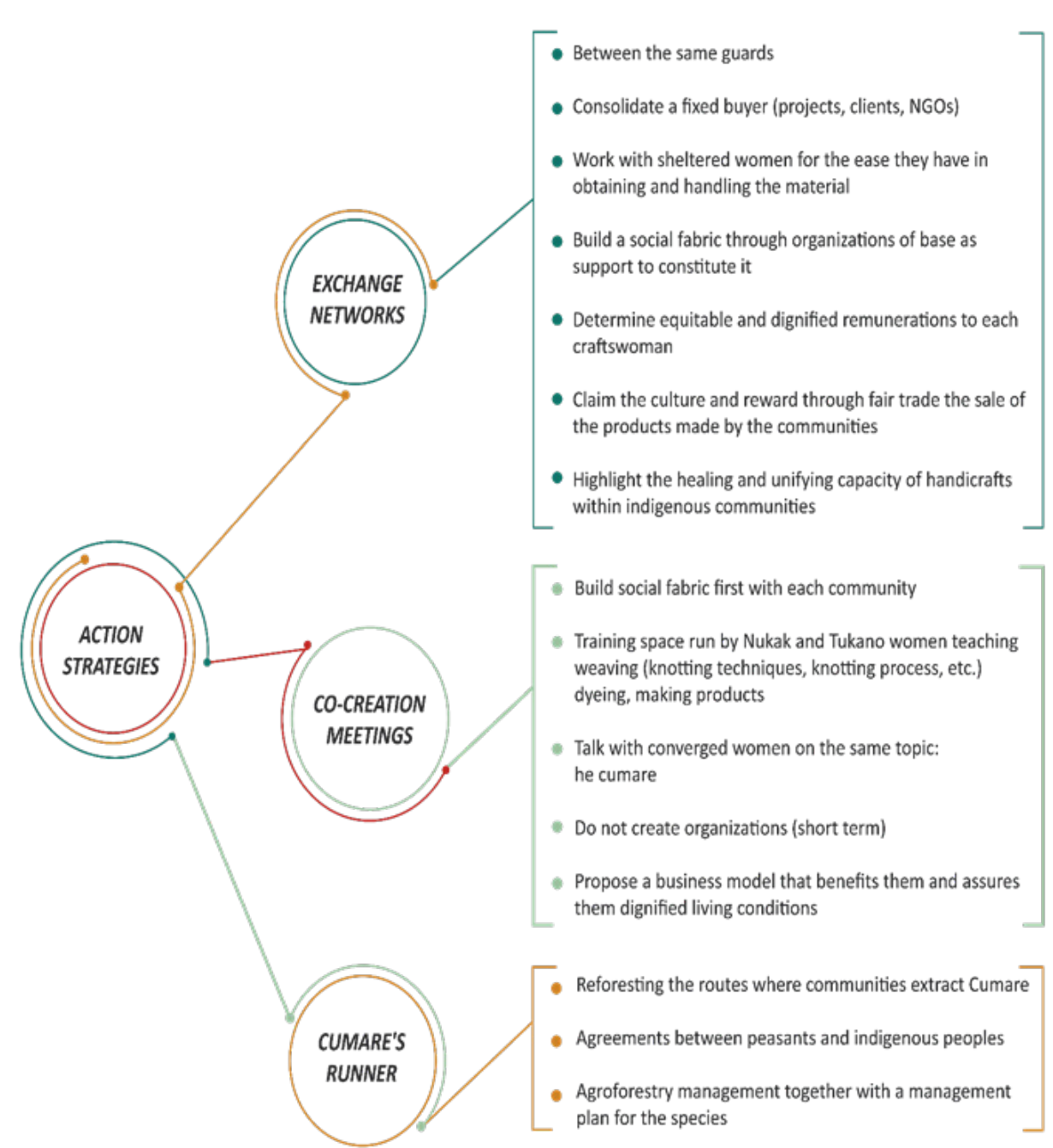

Font: Author. 


\subsubsection{Implementation of the socio-economic strategy}

The implementation of the chosen strategy (fig. 9) is based on several aspects relevant to the process, such as: the appropriation of an adequate management of non-timber forest resources by adopting harvesting methods, regeneration and sustainable growth for the palm population (BOEGE, 2000). To this end, priority measures should be structured that assign responsibilities where budgets, work plans and indicators are determined to evaluate achievements (GARCÍA CASTRO, 2013). Also the opening of marketing channels linked to nature tourism inviting to care, protect, respect and know the territory. In addition, to propose a seal of origin that identifies the added value in the products produced by means of the circular value system covered by the good conservation practices of the species (GARCÍA CASTRO, 2013) the recognition of collective work and social empowerment.

Fig. 9 - Exchange networks strategy

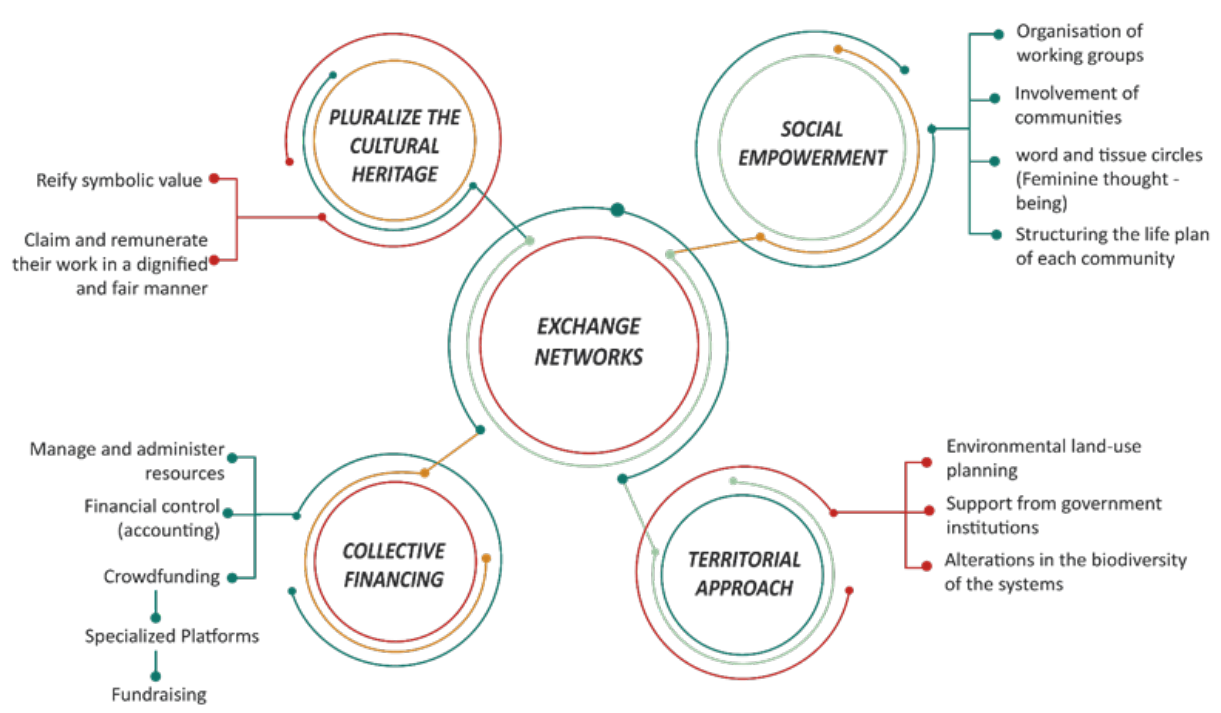

Font: Author. 


\section{CONCLUSION}

The communities are seeking to restore the territories affected by deforestation, since the Amazon region currently accounts for $70 \%$ of deforestation in Colombia, according to the 2018 IDEAM report. These ethnic groups consider a change in public policies necessary, that manages to disempower capital that deforesters and carries out unsustainable land management practices, granting benefits to extractive industries and allowing land use to be regulated by giving sovereignty to indigenous and peasant adequate monitoring of government institutions, This proposal proposes a viable solution for the conservation of protected and exploited areas, allowing communities to improve their living conditions. Although much of indigenous knowledge and practice It is essential that members of these communities appropriate the natural resources characteristic of the region, who know the properties and behavior of the plant materials used in the great variety of their handicrafts and artifacts of daily use to boost the economy of their own and the region through the identity of the territory with a participatory planning of rural communities where a biodiversity management plan is established aimed at the preservation and responsible use of natural resources.

It is necessary to involve indigenous communities in the formulation of strategic actions that consolidate collaborative processes of land planning and management. In this sense, building a solid social fabric through the formation of grassroots organizations allows the management of projects with the communities as a socio-economic strategy that directly benefits the population.

Finally, it is important to carry out more detailed research studies on the ecology and genetic diversity of Astrocaryum chambira burret palm to reforest these populations in area and optimize the plant resource within a systemic approach to sustainable development, because the fiber proves to have adequate physical and mechanical conditions to produce. 


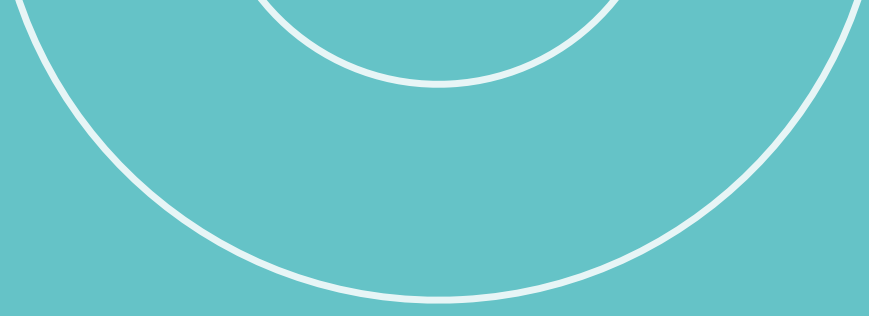

BIBLIOGRAPHY

1. BERNAL, Rodrigo; GALEANO, Gloria (ed.). Cosechar sin destruir: aprovechamiento sostenible de las palmas colombianas. Bogotá: Facultad de Ciencias, Instituto de Ciencias Naturales, Universidad Nacional de Colombia, 2013.

2. BOEGE, Eckart. Protegiendo lo nuestro: manual para la gestión ambiental comunitaria, uso y conservación de la biodiversidad de los campesinos indígenas de América Latina. México DF: Instituto Nacional Indigenista, 2000.

3. BRAÑAS, Manuel; MASS HORNA, Wagner. Palmeras nativas: conservación y manejo en la zona de amortiguamiento de la reserva nacional Pacaya Samiria. Cuenca baja del río Marañón. Lima, Peru: Ministerio del Ambiente, 2011. P56. Programa de Cooperacion Hispano Peruano, Lima (Peru).

4. CARRERA MORALES, Darwin Rafael. Desarrollo comunitario en la ciudad de Ambato, Ecuador: evaluando necesidades y potenciando el sentimiento de comunidad. 2015. Tesis Doctoral (Doctorado en Pedagogía Política Curricular y Social) -Universidad de Burgos, España, Burgos, 2015.

5. ESCOBAR, Arturo. Autonomía y diseño: la realización de lo comunal. Colombia. Editorial Universidad del Cauca, 2016.

6. GALEANO, Gloria; BERNAL, Rodrigo; ISAZA ARANGUREN, Carolina, NAVARRO LÓPEZ, Jaime Alberto; GARCÍA, Néstor, VALLEJO, Martha Isabel; TORRES, Claudia Eugenia Toca. Evaluación de la sostenibilidad del manejo de palmas. Ecología en Bolivia, La Paz, Bolivia, BO, v. 45, n. 3, p. 85-101, Dic. 2010.

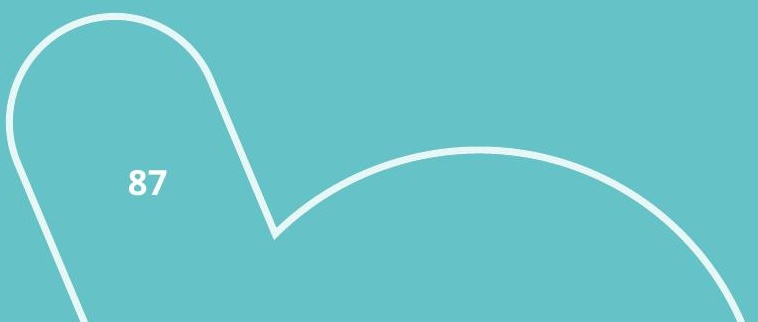


12. TOBAR, Javier; ZARATE, Albert; GROSSO, José Luís. Patrimonio cultural en tiempos globales. Popayán, Colombia: Editorial Universidad del Cauca, 2018.

13. TRÉLLEZ, Eloísa; QUIROZ, César. Formación ambiental participativa. Una propuesta para América Latina. Lima, Perú: Centro Ambiental Latinoamericano de Estudios Integrados para el Desarrollo Sostenible, 2015.

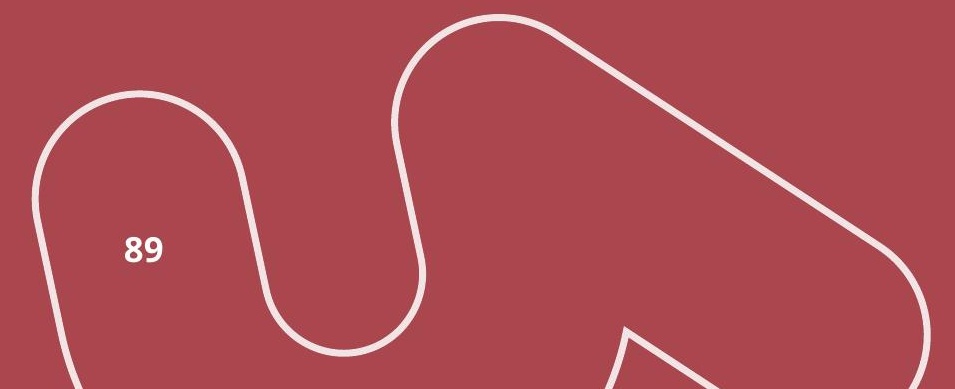

